\title{
Die rol van die Ou Testament in die ordening van die samelewing by A A van Ruler
}

\author{
Colin Hertzog \& Andries Breytenbach ${ }^{1}$ \\ Departement Ou-Testamentiese Wetenskap \\ Universiteit van Pretoria
}

\begin{abstract}
The role of the Old Testament in the arrangement of society as applied by A A van Ruler

This study considers A A van Ruler's position with regard to theological themes like eschatology, theocracy, torah and volkskerk. It endeavours to grasp Van Ruler's understanding of the Old Testament as the norm for establishing a theocratic social order. The following two conclusions are reached: the context of the Old Testament must be taken into account when interpreting it or when drawing support from it, and the Old Testament should not be used to back up preconceived notions about theocracy and the arrangement of society. The influence Van Ruler exercised on the Nederduitsch Hervormde Kerk compels this church to reconsider its position with regard to his points of view.
\end{abstract}

\section{INLEIDING}

A A van Ruler het ' $n$ "sterk invloed op die teologie binne die Nederduitsch Hervormde Kerk van Afrika uitgeoefen" (Van Wyk 1990:498). Dit kan nie ontken word nie. Veral by teologiese temas soos die teokrasie en die nadenke oor die volkskerk, was sy invloed groot (Die Hervormer 1997a:2; 1997b:6). Die aktualiteit van Van Ruler se teologie word bevestig in ' $n$ debat in die Nederduitsch Hervormde Kerk van Afrika [Kerk] oor die vraag of die Kerk 'n kultuurtaak het, soos weerspieël in die vierdie aflewering van die Hervormde Teologiese Studies, volume 52. Van Ruler word gereeld in die debat aangehaal. Een van die standpunte in die debat is dat die Kerk wél 'n kultuurtaak het, alhoewel dit nie altyd 'n direkte kultuurtaak is nie. Dreyer (1996:886) sê byvoorbeeld

\footnotetext{
${ }^{1}$ Hierdie artikel is ' $n$ verwerking van die MDiv-skripsie wat voorberei is onder leiding van prof dr A P B Breytenbach en in 1999 aanvaar is deur die Fakulteit Teologie, Universiteit van Pretoria.
} 
dat, as die evangelie werklik tot die hart van die mens wil spreek, dit inheems sal moet word aan 'n bepaalde kultuur. Deurdat gelowiges die evangelie ernstig neem, het dit 'n vormende uitwerking op die kultuur. Botha (1996:818) vra op sy beurt of die teokrasie, wat ook 'n wyse van inrigting van die samelewing impliseer, prysgegee kan word. Ander teoloë sê weer dat die Kerk geen kultuurtaak het nie (vgl bv Breytenbach 1996:712; Pelser 1996:731). Dat Van Ruler se invloed gegeld het by sommige deelnemers aan hierdie debat, is duidelik. Dit het daarom sin om Van Ruler se teologie, en meer spesifiek sy gebruik van die Ou Testament, te ondersoek.

Van Ruler gaan in sy teologie baie sterk uit van die Ou Testament. In die Ou Testament word God se bedoeling met die wêreld vir hom duidelik. Die hele menslike eksistensie kan, en behoort volgens Van Ruler, uit die riglyne wat die Ou Testament verskaf, georden te word (Van Ruler 1945:127; 1947a:115, 267).

Die doel van hierdie studie is om aan te toon dat Van Ruler se verstaan van die Ou Testament deur sy dogmatiese invalshoek beïnvloed is en dat sy standpunt oor onder. andere die volkskerk, wat 'n uitvloeisel is van sy verstaan van die teokrasie, nie sonder kritiese beoordeling aanvaar kan word nie. Met die oog daarop word die vernaamste dogmatiese uitgangspunte van Van Ruler eers aan die orde gestel. Daarna sal enkele paragrawe gewy word aan Van Ruler se gebruik van die Ou Testament, gevolg deur 'n evaluering daarvan.

\section{VAN RULER SE TEOLOGIESE VERTREKPUNTE}

\subsection{Eskatologie beteken dat God vanuit die toekoms na ons toe kom}

Volgens Velema (1962:11) wil Van Ruler 'n eskatologiese teologie opbou. Onder eskatologie verstaan Van Ruler dat God ons vanuit die toekoms tegemoet kom. Daarom sê Van Ruler (1947a:26) "moeten wij in het dogmatische denke by het einde beginnen en dan van daaruit terugziet, of liever: terug wàndelen ... naar het kruis, en ... tot in het begin der schepping en zondeval. Wij bewegen ons in het handelen Gods, dat alleen vanuit het einde te verstaan is." Dit gaan dus hier oor die histories-eskatologiese handelinge van God. Op grond hiervan sê Van Ruler (1947a:26) dat "het geheele geloofsbelijdenis als met rugwaarts gaande beweging van de eschatologie uit gevorm ... worden. In 
het licht van het Woord Gods staat alles gericht op zijn bestemming, is het van daaruit geordend en gevorm, en kan het van daaruit alleen verstaan worden."

Hierdie is 'n baie belangrike sleutel tot die verstaan van Van Ruler se teologie. Vanuit die eskatologie moet alles uitgelê en "gevorm" word. "Ordening" en "vormgewing", soos in bogenoemde aanhaling, is twee begrippe wat dikwels in Van Ruler se teologie na vore kom. Die feit dat Van Ruler die samelewing vanuit die Ou Testament wil orden, se wortels lê hier. Van Ruler se hele teologie moet dus gesien word in die lig daarvan dat God die mensdom vanuit die toekoms tegemoet tree in die hede.

"Van hieruit wil Van Ruler nu verschillende bijbelse termen verstaan en vullen. Daar is allereerst de eschatologise waarheid van het koninkrijk Gods" (Velema 1962:13). Die koninkryk van God is vir Van Ruler "nie alleen 'n saak van die toekoms ... nie, maar ook 'n werklikheid in die hede" (Engelbrecht 1963:3), want God skep vanuit die eskaton die koninkryk in die hede. In hierdie paradoks word die werklike karakteristiek van die koninkryk afgespieël (Van Ruler 1945:58). Wat is die koninkryk van God vir Van Ruler? Dit is die "uiteindelike heilryke handele van God met hierdie wêreld" (Engelbrecht 1963:16; vgl ook Velema 1962:13). Deur die handelinge van God met hierdie wêreld word die wêreld die heil in Christus deelagtig (Engelbrecht 1963:19). Ook in hierdie heilryke handelinge van God is daar 'n noue verband tussen die hede en die einde. Alhoewel God in sy handelinge met die wêreld die wêreld vanuit die toekoms ontmoet, "kan Van Ruler er niet van tussen uit om in de werken Gods toch de voortgang naar het einde op te merken" (Velema 1962:14). Hierdie perspektief word egter nie by Van Ruler ontgin soos die gedagte dat God vanuit die toekoms na ons toe kom nie. Van Ruler sien die toekoms reeds in die hede deurdat die eskaton in die hede ingedring het. Daarom is die hede eskatologies bepaal (Velema 1962:15).

Die doel van hierdie studie is nie om op hierdie uitgangspunt van Van Ruler in te gaan nie. Dit is eerder om aan te toon hoe hierdie uitgangspunt by Van Ruler die gevaar inhou om die etiek te oorbeklemtoon. Van Ruler ontken hierdie moontlikheid deur te sê dat so 'n verstaan van die ryk van God die "ryksgedagte van sy eskatologiese wese beroof' (Engelbrecht 1963:13). Tog kan Van Ruler se dogmatiese uitgangspunt nie vrykom van 'n oproep tot 'n veretisering van die ryk van God in die hede nie. Dit lei noodwendig tot die skep van vorme asof dit direk van God afkomstig is. Dit sal later in 
die studie uit die briefwisseling tussen Haitjema en Van Niftrik (1956:3-33) duidelik blyk.

Die ryk van God, soos dit in die menslike eksistensie na vore kom, kan volgens Van Ruler net verstaan word vanuit die noue verband tussen die Messias en die ryk van God. Velema (1962:16) stel dit soos volg: "Door de nauwe verbinding tussen het rijk van God en Christus wordt tevens duidelijk, dat het rijk van God in het dood gefundeerd staat. De dood van Christus is het offer. Door de dood is de schuld gedragen en verzoend. Daarmee is het koninkrijk gesticht en de wereld gered."

Vanuit die koninkryk word die wêreld dus vervul, vol gemaak, met die heil wat in Christus gekom het. Dit is 'n "rugwaartsgaande beweging vanuit die einde tot in die begin terug, tot daar waar die mens in al sy liggaamlikheid ... in al sy stoflikheid staan" (Engelbrecht 1963:20). Alles in die hede word deur die eskaton bepaal. Nie deurdat alles op pad is na die eskaton nie, maar deurdat die eskaton na ons toe kom en alles vervul, en dan juis vervul met die heil in Christus. Daar is dus 'n identiteit tussen hierdie wêreld en die toekomende, alhoewel die heil nie tot die wese van die wêreld behoort nie (Engelbrecht 1963:20). In die uitspraak dat daar 'n identiteit bestaan tussen hierdie wêreld en die toekomstige, lê die weg oop om vorme in die wêreld te skep wat as tekens van die ryk van God kan dien.

\subsection{Die Heilige Gees skep gestaltes van die ryk van God}

Vir Van Ruler is die rol van die Heilige Gees onmisbaar in die verlossing van die wêreld. Alle handelinge van God in die hede is handelinge deur die Gees (Velema 1962:56). Hesselink (1973:84) sê dat Van Ruler saam met Calvyn genoem kan word as 'n teoloog van die Heilige Gees, maar dat hy sy teologie van die Heilige Gees verder uitbou as Calvyn. Ook Fries (1973:125) sê: "For Van Ruler the lines are drawn and intersect through the pneuma of God. The Spirit fills existence with messianic redemption, the eschaton arches into the present, existence becomes historical, the law of God takes form in the affairs of men ...."

Deur die werk van die Gees word die heil in Christus heil vir die wêreld. Engelbrecht (1963:61-62) vat dit so saam: 
Rondom die kruis van Golgota, is die christelike eksistensie kulties gestruktureer, en onder "kulties" word hier verstaan histories-kulties, dit is die heiliging, waarin die offer van die versoening, in kosmiese en wêreldhistoriese sin, deur die Gees aan die ganse eksistensie voltrek word, sodat die gewone lewe van elke dag in die samelewing van die mense, in die historiese realiteit, as offer aan God geleef word.

Die werk van die Heilige Gees mag egter nie eensydig van Jesus Christus uit verstaan word nie. Dit moet in die nouste verband met die koninkryk van God verstaan word. God kom ons vanuit die toekoms deur die Gees tegemoet (Engelbrecht 1963:62; Velema 1962:59-62; Fries 1973:133). Ook die werk van die Gees het dus 'n eskatologiese bepaaldheid. Deur die Gees kom God die wêreld met die heil van Christus tegemoet.

Van Ruler meen dat die werk van die Gees nie bloot misties verstaan moet word nie, "maar dat ook in die sakramente en die geskiedenis en die gekerstende kultuur en die teokratiese staat die werk van die Gees geglo sal word" (Engelbrecht 1962:63). Die Gees is nie op 'n mistiese wyse betrokke in die wêreld nie, maar histories, want vir God gaan dit om hierdie wêreld. "Die ganse werklikheid kom ... in die gesigsveld, die ganse gekerstende en te kerstende eksistensie, en alle waarheid van God is ... waarheid op die wyse en in die krag van die Heilige Gees" (Engelbrecht 1963:63). Omdat die Gees in die nouste verband met die koninkryk van God staan, rig die Gees ook gestaltes van die koninkryk in die hede op (Fries 1973:132; Velema 1962:81-92). Van Ruler (1947b:6) sê dat die Gees voortdurend gestaltes skep na die beeld van God in die individuele, sowel as in die gemeenskaplike lewe. Hierdie gestaltes is onder andere die kerk en die ampte, die teokratiese staat en die volkslewe. Van Ruler (1947b:147) sê byvoorbeeld in verband met die kultuur van Europa die volgende: "De Geest is boven alles degene, die geschiedenis schept. En de gekerstende cultuur van Europa is werk van den Heiligen Geest en als zoodanig gestalte van het koninkrijk Gods."

Uitsprake soos hierdie is problematies. Dit kan daartoe lei dat sekere gestaltes wat van die Gees kom, verabsoluteer word; beide omdat daar geoordeel kan word dat dit van God kom en omdat die spesifieke gestalte van groot waarde kan wees vir 'n sekere geloofsgemeenskap. Volgens Fries (1973:132) is Van Ruler bewus van die gevaar. Hy 
sê dat die veelheid van die gestaltes van die Gees elke gestalte so relativeer dat dit nie die gevaar inhou om verabsoluteer te word nie. Van Ruler (1947b:32) relativeer hierdie gestaltes, of vorme, wat deur die Gees geskep word, verder deur te sê dat al die eksperimente van God op aarde in elk geval misluk. Dit gebeur omdat die Christendom altyd 'n vermenging van Christendom en heidendom is (Velema 1962:77). In die volgende aanhaling word die standpunt duidelik gestel: "Het is het a.b.c. van alle christelijke levenswijsheid, om het relatieve serieus te nemen. De gansche geschapen, gevallen, versoende en ter verlossing bestemde existensie verloopt geheel en al in de relativiteit. De greep naar het absolute is juist de kern van de zonde" (Van Ruler 1947c:276).

Alhoewel dit nie die bedoeling van Van Ruler is dat sekere gestaltes van die Gees verabsoluteer moet word nie, bly die gevaar steeds groot dat die gevolgtrekking gemaak kan word. Hierdie neiging kom gereeld in sy teologie voor. Dit word onder andere bevestig in sy uitspraak dat die "orde" die enigste Christelike is wat ons in die wêreld kan hê (Van Ruler 1945:109). Dit word ook bevestig in die wyse waarop Van Ruler die teokrasie en die volkskerk verdedig (kyk Botes 1996:938). Hesselink (1973:83) is daarom korrek as hy sê: "Van Ruler, in his extreme consistency, so emphasizes the role of the Spirit and the kingdom that Christ and the church do not always receive their due."

\subsection{Die volle konsekwensies van Van Ruler se eskatologie}

In ' $n$ briefwisseling tussen Haitjema en Van Niftrik sê Van Niftrik dat beide Haitjema en Van Ruler nie die volle konsekwensies van die eskatologie verstaan nie (Haitjema \& Van Niftrik 1956). Vanuit sy dialektiese denke sê Van Niftrik dat Haitjema en Van Ruler die woord eskatologie dikwels gebruik, maar dat hulle eskatologie nooit die radikaliteit bereik waar dit vorme stukkend breek, en die gemeente slegs lewe in die verwagting van Hom wat kom nie (Haitjema \& Van Niftrik 1956:14). Die verskil in die verstaan van die eskatologie tussen Haitjema en Van Ruler enersyds, en Van Niftrik andersyds, kan saamgevat word met die woorde:

... [H]et eschatologische heilshandelen Gods schept bij Van Ruler en u vormen, terwijl het naar mijn inzicht vormen breekt. Ik heb in het bijzonder bij Van Ruler veel gelezen over de gestalten en vormen, die het Rijk Gods aanneemt in de gemeenschappelijke existentie van de mens, in staat en cul- 
tuur, evenzeer in de individuele existentie van de mens tot in de ontroeringen van zijn bloed toe ... maar ik ben er niet van overtuigd, dat dit bijbelse eschatologie is.

(Haitjema \& Van Niftrik 1956:15)

Bybelse eskatologie staan meer krities teenoor vorme. Dit relativeer alle vorme en lewer 'n etiek wat minder seker is oor etiese vrae as wat Van Ruler is oor 'n saak soos die doodstraf (Haitjema \& Van Niftrik 1956:15). Die gestaltes van die Gees, en spesifiek kultuurgestaltes, kan wel tekens wees van die koninkryk van God danksy die genade van God, maar dan is elke gestalte juis as gestalte verraad teen die evangelie (Haitjema \& Van Niftrik 1956:16-17). Van Ruler se eskatologie skiet juis daarin tekort dat dit nie in wese Christologie is nie. Eskatologie beteken vir Van Niftrik dat ons Jesus Christus tegemoetgaan. Dit beteken dat die kruis van Christus oor die wêreld, sy geskiedenis, state, volke en vorme uitgeteken staan (Haitjema \& Van Niftrik 1956:16). Eskatologie is daarom sterk op die toekoms gerig. 'n Terugskouing na die verlede is 'n vorm van ongeloof, want ons gaan die toekoms tegemoet (Haitjema \& Van Niftrik 1956:18). As Haitjema (Haitjema \& Van Niftrik 1956:27) hierop antwoord deur te sê dat Van Niftrik nie alle vorme deur die eskatologie as gebreek en gerelativeer kan verstaan nie, omdat Jesus Christus self die gestalte van 'n dienskneg aangeneem het, sê Van Niftrik (Haitjema \& Van Niftrik 1956:30-31) dat selfs hierdie gestalte aan die kruis gebreek is.

Omdat die fokus vir Van Ruler op die eskaton val, wat op sy beurt terugwerk tot in die hede, kry die Christologie nie die nodige aandag in die teologie van Van Ruler nie (Hesselink 1973:83). Van Ruler sou dit ontken. In die slotsinne van sy laaste teologiese referaat, in September 1969, sê hy dat hy nie pleit vir pneumatologiese teologie in die plek van 'n Christologiese teologie nie. Teologie moet eerder trinitariese teologie wees (Van Ruler, in Kempers 1997:xxxi). Dit lyk egter of Hesselink korrek is in sy uitspraak. Vir Van Ruler beteken die eskatologie juis nie dat ons die toekoms tegemoet gaan nie. Dit beteken eerder dat God vanuit die toekoms na ons toe kom en dat hierdie ontmoeting van God met die eksistensie terugwerk tot in die skepping (Van Ruler 1947a:26; kyk ook Berkhof 1990:510-512). Dit veroorsaak 'n terugskouing na die verlede, of in Van Ruler se woorde self, 'n rugwaartsgaande beweging (Engelbrecht 1963:20), wat op sy beurt 
beteken dat die vorme en gestaltes wat vir die hede belangrik is, in die verlede gesoek word (vgl Berkhof 1990:246) en deur die Gees in die hede nuut opgerig word.

Van Niftrik se verstaan van die estatologie is sekerlik ook nie sonder tekortkominge nie, maar dit werp waardevolle lig op Van Ruler se teologie en sy gebruik van die Ou Testament. Die klem wat Van Ruler op die eskatologie plaas, sonder dat dit werklik 'n tegemoetgaan van Jesus Christus in die oog het, verklaar Van Ruler se belangstelling in die Ou Testament. God se teruggrype vanuit die eskaton werk terug tot in die skepping. So word die Ou Testament deur Jesus Christus vervul en van krag gemaak.

\section{VAN RULER EN DIE OU TESTAMENT}

Van Ruler het in sommige van die artikels en boeke wat hy geskryf het, verskeie kontroversiële uitsprake oor die Ou Testament gemaak. Onder dié uitsprake tel die volgende:

- Die Nuwe Testament leer ons die "dat" van Christus, terwyl die Ou Testament ons die "wat" van Christus leer (Van Ruler 1945:126).

- Die Ou Testament is die eintlike Bybel, ook vir die kerk, terwyl die Nuwe Testament niks meer is as ' $n$ lysie met vreemde woorde ter nadere verklaring agter in die Bybel nie (Van Ruler 1945:123). Dit maak die Ou Testament volledig (Van Ruler 1945:142).

- Die Ou Testament moet geïnterpreteer word as die getuienis aangaande Jesus Christus. As dít nie deur die Christendom erken word nie, hef hy homself op (Van Ruler 1945:125).

- Dit is nie voldoende om net te erken dat daar sekere Ou-Testamentiese tekste is wat Messiaans uitgelê kan word nie. Dit is nodig om te besef dat ons uit die hele Ou Testament kennis aangaande Christus kan put (Van Ruler 1945:129). Die hele Ou Testament moet in die lig van Christus gelees word (Van Ruler 1971:19-20, 46).

- $\quad$ Die Nuwe Testament kan en mag nie iets anders wees as die regmatige uitlegging van die Ou Testament nie (Van Ruler 1945:125). 
- As dit dan so moeilik is om Christus in die Ou Testament te vind, is dit dan enigsins moontlik om Hom in die Nuwe Testament te vind (Van Ruler 1945:149)?

- Die Ou Testamentiese tora wil die hele menslike eksistensie tot in sy fynste besonderhede orden (1947b:115).

Van Ruler (1945:123) is bewus daarvan dat sommige van hierdie stellings aandag trek en teenkanting uitlok. Hy verduidelik dit daarom in sy werk Religie en Politiek (Van Ruler 1945:123-149). Ongelukkig verduidelik hy nie in dié gedeelte hoe sy verstaan van die Ou Testament in die groter geheel van sy teologie inpas nie. In die volgende paar paragrawe word hieraan aandag gegee.

\subsection{Die vervulling van die wet}

Die titel Van Ruler (1947a) se proefskrif, naamlik De vervulling van de wet, verraai reeds die feit dat dit in sy uitleg van die Ou Testament gaan om die betekenis van die $\mathrm{Ou}$ Testament vir die vormgewing van die menslike eksistensie. Die subtitel van die proefskrif: Een dogmatische studie over de verhouding van openbaring en existentie gee iets hiervan weer. Die vervulling van die Ou Testament beteken nie die ontbinding of afskaffing van die Ou Testament, en daarmee saam die wet, nie (Engelbrecht 1963:222). Dit beteken eerder dat die Ou Testament waar gemaak word, van krag gemaak word, dat daaraan sin gegee word, dat die doel daarmee bereik is deur wat God in en aan Christus gedoen het (Engelbrecht 1963:223; Van Ruler 1970:70). "[D]e levende God heeft zich in de messianiteit van Jesus aan zijn woord gehouden" (Van Ruler 1947b:108). Omdat die Ou Testament van krag gemaak word deur die vervulling, het dit soveel waarde vir die menslike eksistensie vandag.

Die vervulling van die Ou Testament moet in die lig van Jesus se hemelvaart gesien word. Van Ruler (1945:138) sê "dat men de categorie 'vervulling' en daarmee de waarde van het Oude Testament moet verstaan vanuit de hemelvaart". Jesus se hemelvaart het sy messianiteit bekragtig. Juis dáárom vervul Hy alle dinge. Hy vervul dit in 'n drievoudige sin. Hy maak dit vol, gee dit sin en laat dit tereg kom (Van Ruler 1945:138-141; Engelbrecht 1963:222-223). Dit geld ook vir die Ou Testament. "[D]e vervulling van de dingen van het Oude Testament beteekend ... dat zij ... juist tot teeken 
ten volle gemaakt en als teeken ingezet zijn voor alle volkeren" (Van Ruler 1945:141). Jesus maak die Ou Testament geldig en rig dit tot teken op vir die ganse eksistensie.

Wat verstaan Van Ruler onder "die wet"? Dit is belangrik om die vraag te beantwoord, aangesien Van Ruler (1947a:267) sê dat die wet die samelewing orden en die medium is tussen openbaring en eksistensie. Die sleutel tot die verstaan van wat Van Ruler bedoel met die "wet" lê in die Hebreeuse woord tora opgesluit (Van Ruler 1947a: 269). Die woord tora dui op onderwysing, in die sin van: die weg aanwys (Van Ruler 1947a:269; Engelbrecht 1963:214). Die wet van God moet dus nie gesien word as vaste reëls en gebooie nie, maar eerder as die handelinge van God waarin God vanuit die toekoms die wêreld tegemoet kom. Die hele Ou Testament bevat dus die wet. Dit gee onderwysing en dui die weg aan. Omdat die wet gesien moet word as die onderwysing van God moet dit dus nie as 'n onderdeel van die Ou Testament nie, maar juis as die sentrale inhoud van die Ou Testament gesien word (Engelbrecht 1963:215). Die hele Ou Testament het immers waarde as bron vir onderwysing.

Omdat die Ou Testament die koninkryk van God wil verkondig (Van Ruler 1971:77; Engelbrecht 1963:1) moet die wet dus ook gesien word as die wyse waarop die ryk van God in die hede opgerig word (Velema 1962:42-43). Die wet wil nie net die koninkryk verkondig nie, maar ook gesaltes van die koninkryk in die hede oprig. Dit is juis met die oog op die oprigting van die gestaltes dat die Ou Testament vir Van Ruler so belangrik is. Rasker (s a:19) sê dat dit vir Van Ruler, in die lang tussentyd voor die wederkoms, nodig is dat die mensdom lewensvorme vind wat bepaal word deur die openbaring van God. "Waar zullen we die beter vinden dan in het Oude Testament, dat de bijbel was van Israël en van Jesus en de apostelen en van de oude kerk?" (Rasker sa:19). Daarom is die volgende van die Ou Testament as tora waar:

De thora ontwerpt een eigen gestalte des levens, een levensvorm voor het volk en voor den enkeling. $\mathrm{Zij}$ is, onder alles wat zij bovendien nog is, een ordening der existentie van totalitaire allure. Totalitair in den extensieven zin van het woord, inzooverre zij het geheele leven, vaak tot in het minutieuse toe, wil ordenen. En ook totalitair in den intensieven zin van het woord, inzooverre zij alle momenten des levens in de onmiddellijke nabijheid en onder het onmiddellijke beslag van de heiligheid van den levenden God, die in 
de existentie is binnegetreden, wil stelten. Dit is het punt, waar voor mijn betoog alles op aankomt.

(Van Ruler 1947b:115)

Van Ruler (1947a:271) probeer hierdie gedagte ook weergee deur te sê dat die wet die medium tussen openbaring en eksistensie is. Dit beteken dat wanneer die openbaring in die eksistensie ingaan, die wet daarin bemiddel. Die wet is die beginsel waarvolgens die eksistensie vanuit die heil georden word (Velema 1962:41). Die vormgewende karakter van die wet kan nie hierin gering geskat word nie.

Omdat die heil die wet voorafgaan, deurdat Jesus Christus die wet vervul, is die wet die vorm van die evangelie. Hiermee is alles, volgens Velema (1962:42), egter nog nie gesê nie, "[w]ant al gaat het evangelie aan de wet vooraf en al is de wet de vorm van het evangelie, toch is de wet anterieur te achten aan de Messias." Daarom kan die evangelie tydelik en die wet ewig genoem word. Die wet is meer eskatologies as die evangelie (Velema 1962:42). Van Ruler kan dus ook sê dat die evangelie niks anders is as 'n vorm van die wet nie (Velema 1962:43). Hierdie gedagte by Van Ruler maak dit moontlik om die klem so op die Ou Testament te plaas dat die Nuwe Testament op die agtergrond raak. Dit dra verder ook daartoe by dat die Christologie, soos reeds aangedui, nie sy regmatige plek in die teologie van Van Ruler kry nie. Dit word duidelik in die volgende aanhaling:

Die uiteindelike bedoeling van God met hierdie wêreld word in die wet so volkome uitgedruk dat die eskatologiese gehalte daarvan groter is as die van die evangelie, en moet die gawe van die Messias en die uitstorting van die Gees in 'n sekere sin selfs ondergeskik geag word aan die gawe van die wet. Die gawe van die Messias en die gawe van die Gees is in die heilshandele van God nie sy uiteindelike doel nie, maar middel tot sy uiteindelike doel, nl. die ryk van heerlikheid.

(Engelbrecht 1963:217)

Van Ruler se stelling dat die woord tora dui op onderwysing, eerder as op vaste reels en orde, vind in sy teologie nie werklik neerslag nie. As medium tussen openbaring 
en eksistensie kry die tora so 'n belangrike rol dat dit wel in 'n sekere sin verabsoluteer word as enigste norm vir die skep van gestaltes deur die Gees en as norm vir die inrigting van die samelewing.

\subsection{Die betekenis van die Mosaïese wet}

Die belangrikheid van die Ou Testament in die teologie van Van Ruler word duideliker in die lig van wat hy oor die Mosaïese wet sê. Van Ruler (1969:134) onderskei tussen die:

- Kerugmatiese betekenis van die Mosaïese wet. Hieronder verstaan Van Ruler dat dit die Mosaiese wet is waaraan die begrippe, inhoude, uitdrukkings en vorme ontleen word vir die verkondiging van Jesus Christus.

- Eksistensiële betekenis van die Mosaiese wet. Dit was die Mosaïese wet wat die soenoffer van Jesus Christus noodsaaklik gemaak het en aan die Christelike eksistensie 'n kultiese struktuur gegee het.

- Funksionele betekenis van die Mosaïese wet. Die Mosaïese wet beskryf die funksie van die gestaltes wat in die wêreld deur die kerstening in die lewe geroep word in die geheel van die koninkryk van God.

- Materiële betekenis van die Mosaïese wet. Die grondlyne en materiaal wat gebruik word om in die kersteningsarbeid die wêreld Christelik in te rig, word aan die Mosaïese wet ontleen.

Dat al vier hierdie punte nie reg laat geskied aan die betekenis van die Mosaïese wet nie, is duidelik, maar dit is nie nou ter sake nie. Omdat hierdie studie geïnteresseer is in die ordening van die samelewing, is die materiële betekenis van die Mosaiese wet hier verder van belang. Die volgende aanhaling bring die materiële betekenis van die wet goed na vore:

De gehele existentie komt uit de thora voort: het huwelijk, de geslagtelijkheid, de eigendom, het recht, de straf, de staat, enz. Gaat het er om, het leven van de enkeling en van de gemeenschap waarlijk christelijk, dat is waarlijk vanuit de kennis van de Here, zijn heil en zijn recht, in te richten, dan zal men de 
mozaïsche wet hebben toe te passen op en op te leggen aan de volkeren van de aarde. Ook de mozaïsche wet behoort tot de openbaring van de levende God aan Israël en - in Israël - aan de wereld.

(Van Ruler 1969:143)

Omdat die materiële betekenis van die wet so belangrik is, is die liturgie in die gereformeerde tradisie ook korrek deur die wetlesing deel van die erediens te maak. Maar dit mag nie net verstaan word as die kenbron van die sonde, en die riglyn tot 'n lewe van dankbaarheid nie. Dit moet eerstens gesien word as die vorm van die ryk van God waarin die sin en die bestemming van die wêreld lê. Omdat die verkorte wet uit die Nuwe Testament nie in dieselfde mate aan die vereiste voldoen nie, verkies Van Ruler dat die tien gebooie uit die Ou Testament voorgelees word (Van Ruler 1971:150-151).

Vanuit die tora kan die hele eksistensie dus omvorm word tot, en ingerig word as, die koninkryk van God in die hede. Dit beteken, volgens Van Ruler (1969:143), nie dat die wet kunsmatig, in 'n ander tyd en omstandigheid as toe die wet aan Israel geopenbaar is, ingevoer mag word nie. Die Mosaiese wet mag nie letterlik ingevoer word nie. Dit is 'n aantasting van die wet as dit letterlik ingevoer word (Van Ruler 1947a:291). Maar dit mag ook nie tot niet gemaak word deur die uitgangspunt dat dit niks meer vir die Christendom te sê het nie: "Het sectarisch-rationeel radicalisme, dat de heele wet van Mozes weer wil invoeren, om een cultuur te ordenen, is kinderspel, vergeleken bij het kerkelijk-apostolisch radicalisme, dat de geheele cultuur gegroepeerd weet rondom het kruis van Golgotha" (Van Ruler 1947b:118).

Die wet is ' $n$ historiese gestalte wat in God se handeling met Jesus Christus geldigheid gekry het vir die hele wêreld. Dit beteken dat dit nie letterlik in die hede ingevoer kan word nie, maar ten volle reëel (Engelbrecht 1963:234). "Die ganse nasionaal-simboliese lewensvorm van die openbaring, soos dit in die Ou Testament gegee is, keer terug in die kultureel-simboliese lewensvorm van die openbaring soos dit geskep word deur die kerstening" (Engelbrecht 1963:234). Die Ou Testament hou 'n lewensvorm aan die wêreld voor wat paradigmatiese betekenis het vir alle kersteningsarbeid in die wêreld. Die Ou Testament is dus onontbeerlik vir die heiliging van die wêreld (Engelbrecht 1963:235). 
In die lig daarvan dat Van Ruler sy werke tydens en na die Tweede Wêreldoorlog skryf, kan iets van die groot belang wat hy by die ordening van die samelewing gehad het, beter verstaan word (vgl Velema 1962:5). Nederland moes weer opgebou word ná 'n verwoestende oorlog. Dit het sekere eise gestel aan die teologie van die tyd, wat op sy beurt ook in die teologie van Van Ruler gereflekteer word. Velema (1962:5) gaan hiermee akkoord as hy sê: "Hy bewoog zich met zijn publikaties midden in de vragen, waarvoor de wederopbouw van Nederland ons volk stelde". Verklaar dit dalk die belang van die ordening van die samelewing, en die skep van vorme, in die teologie van Van Ruler? As dit korrek is, is die vraag of hy, deur die samelewing aan die hand van die $\mathrm{Ou}$ Testament te wil orden, reg laat geskied aan die betekenis van die Ou Testament.

\section{DIE ORDENING VAN DIE SAMELEWING}

Soos reeds angetoon, lei Van Ruler se teologie tot die skep van vorme in die samelewing. Dit is nodig om nader hierop in te gaan deur vir 'n oomblik stil te staan by die vraag na wat Van Ruler oor die teokrasie en die volkskerk sê. Die teokrasie is vir Van Ruler besonder belangrik (Fries 1973:208). Uit die teokrasie vloei ook die volkskerk voort (vgl Van Rooyen 1964:79-80). Oor albei hierdie sake het Van Ruler uitsprake gemaak wat in sommige kringe gewaardeer, en in ander gekritiseer is. Die verhouding tussen die werklikheid en die heil word vir Van Ruler spesifiek in die teokrasie saamgevat (Velema 1962:63). Die volgende paar paragrawe word daaraan gewy om in breë trekke iets oor Van Ruler se teokratiese- en volkskerkdenke te sê. Dit is onmoontlik om in die bestek van hierdie studie al sy standpunte weer te gee.

\subsection{Die teokrasie}

Dit is in byna al die werke van Van Ruler duidelik dat die teokrasie in sy teologie 'n baie belangrike plek inneem (vgl Botes 1996:938). Sommige is daarvan oortuig dat dit die belangrikste plek inneem en noem Van Ruler daarom selfs 'n teokraat (kyk Fries 1973:208; Van Rooyen 1964:268). Die teokrasie is die lewensvorm wat 'n volk aanneem wanneer die lewende God anwesig is en besig is in 'n volk (Hendriks 1977:101-102). Dit geld omdat God ' $n$ God is wat ten diepste geïnteresseer is in die vraag hoe die samelewing van die mensdom ingerig is (Hendriks 1977:102). Die feit dat die ordening van 
die samelewing "vanuit en rondom die waarheid van die heil" (Engelbrecht 1963:89) vir Van Ruler belangrik is, kom goed tot uitdrukking in die volgende aanhaling:

\begin{abstract}
Men kan de theocratie opvatten als politieke vormgeving van het leven en dan denken aan een ordening van de wereld van de kerk uit, zó6, dat het leven er uit komt te zien als een ellips met de twee brandpunten: kerk en staat, of: avondmaal en burgerlijk wetboek. Men kan de theocratie ook opvatten als structuur van theologisch denken; theologie is dan theologie des Wórds, over de heele linie, en niet der zaken; zij is dan critisch, niet ontologisch; praedicatief, niet phaenomenologisch, zij verkondigt alleen en constateert niets. Men kan de theocratie ook opvatten als alsomvattend levensbesef en daarby denken aan een geheel eigen Seinsverstăndnis, dat als bijbelsch-christelijk Seinsverstăndnis onderscheiden is van alle philosophisch-heidensche Seinsverstăndnis en doorgaat tot de laatste en de diepste wortels der existentie, zó dat er geen enkel begrip overblijft, dat niet door de bijbelsche leer wordt aangetast.
\end{abstract}

(Van Ruler 1945:153)

Die rol van die kerk en staat in die ordening van die samelewing blyk dus van groot belang te wees vir Van Ruler. "Als politieke levensvorm wort de theocratie gekarakteriseerd door de tweeheid van kerk en staat" (Velema 1962:73). Dit beteken nie dat kerk en staat los van mekaar staan nie. "Staat en kerk zijn intiem verstrengeld" (Van Rüler 1973:99). Daarom beskryf Van Ruler die verhouding tussen kerk en staat as dié van 'n ellips met twee brandpunte. "Theocracy, as understood by Van Ruler, then, is basically what the word suggests: the rule of God over human life and thus the ordering of existence according to the sovereign will of God. That ordering occurs ... through the bipolarities of church and state, religion and politics, revelation and existence" (Fries 1973:208).

Die eerste brandpunt is dié van die staat. Die feit dat die mens nie net in die kerk leef nie, maar ook in die staat en die volk, gee aan die staat 'n geweldige teologiese betekenis (Engelbrecht 1963:92). Die staat het groot betekenis vir die samelewing se politieke vormgewing, maar ook vir die sosiale, kulturele en ekonomiese vormgewing van die lewe (Engelbrecht 1963:93). Daarom gee Van Ruler soveel aandag aan die staat. 
Die owerheid het die taak om die offer van die versoening in die kultuurlewe van die volk te voltrek (Hendriks 1977:105; kyk Van Ruler 1947b:31). Die owerheid het dus ook 'n soteriologiese betekenis (vgl Velema 1962:91). "Duidelijk is hoezeer Van Ruler de overheid soteriologisch ziet. Er is Gods heilrijk handelen met de wereld. Het recht Gods moet opgericht worden in de chaos van de verloren existentie. Daarin is de overheid de dienaresse Gods bij uitnemendheid" (Hendriks 1977:105). Die staat is dienaar van God, want die wêreld waarin hy optree, is die wêreld van God. "Ook in die staat is $\mathrm{Hy}$ teenwoordig, en in die gesag van die owerheid is dit niks minder nie as die gesag van God self wat oor ons kom" (Engelbrecht 1963:98). Die gesag van die staat lê daarin dat dit dienaar van God is.

Die ander brandpunt in die ellips is dié van die kerk. As die kerk as ander brandpunt ondersoek word, word dit reeds duidelik dat kerk en staat nie sonder mekaar kan funksioneer nie. So weet die staat byvoorbeeld nie wie hy is anders as deur die kerk nie.

\begin{abstract}
Dat die staat uit die natuurreg, uit die historiese proses en uit die rede, uit die natuurlike openbaring veel weet, is stellig waar. Maar die klare kennis van wat hy is, nl. dienaar van God, en waarmee hy besig is, nl. die heilighede van die Here, dit weet die staat alleen vanuit die besondere genade. En hierdie besondere openbaring is aan die kerk gegee. ... Die kerk weet wat die staat nie weet nie, en wat hy weet, mag hy nie verswyg nie; want die kerk is nie daar ter wille van homself nie. ... Hy is ook daar ter wille van die staat, om in die kerugma van die Evangelie van die koninkryk, die owerhede te proklameer en op te roep tot dienaars van God.
\end{abstract}

(Engelbrecht 1963:100)

In die proklamasie van die kerk dat die staat dienaar van God is, verdring die kerk nie die staat nie. "Die koninkryk omvat nie alleen die kerk nie, maar ook die staat" (Van Rooyen 1964:130). Hieruit kan afgelei word dat die apostolaatsfunksie van die kerk vir Van Ruler baie belangrik is (vgl Velema 1962:84-85). Dit gaan dus nie om die kerk as sulks nie, maar om die koninkryk van God wat ook in die breèr samelewing, in die volk, sigbaar gemaak moet word (kyk Engelbrecht 1962:102). Van Ruler (1945:257-265) 
noem nege terreine waarin die kerk hom tot die owerheid kan rig. Die plek waar die kerk die owerheid in die eerste plek aanspreek, is in die prediking. "[D]e prediking is niet aan de gemeente geadresseerd; de gemeente is klankbodem en draagster van de prediking .... Daartusschen in, tusschen de volkeren en de engelmachten ... staan de overheden" (Van Ruler 1945:257). Op die kansel kom alles ter sprake. Die dorpslewe, die vrae van die dag, die ekonomiese en sosiale lewe asook die dinge van die nasionale en internasionale politiek (Van Ruler 1945:258). In die lig van wat reeds gesê is oor die belang van die wet in die Ou Testament is dit nie verrassend om te sien dat die tweede middel waardeur die kerk hom tot die owerheid rig, die korrekte voorlesing van die wet in die erediens is nie (Van Ruler 1945:260). Die derde en vierde middele waarmee die kerk hom dan ook tot die owerheid rig, is die kategismusprediking en die belydenis (Van Ruler 1945:261). Hierna volg die vyfde middel wat die besluite van die kerklike vergaderings is. Die sesde en sewende middele vloei daaruit voort en is onder andere protesaksies (Van Ruler 1945:263). Die agtste is die benoeming van kerklike kommissies om sekere sake soos die verhouding tussen kerk en staat, te ondersoek (Van Ruler 1945:264). . Die laaste en negende middel waardeur die kerk hom met die Woord van God tot die owerheid kan rig, is deur afgevaardigdes van die kerk sitting te laat neem in die kabinet. "Zij hebben natuurlijk geen concludeerdende, doch adviseerdende of praeadviseerende stem" (Van Ruler 1945:265).

Dit is dus duidelik dat die kerk sy stem baie duidelik moet laat hoor teenoor die owerheid. Die feit dat daar 'n dualiteit bestaan tussen kerk en staat, word duidelik gesien in bogenoemde middele wat die kerk kan gebruik om hom te rig tot die staat. Dit hoort ook so, want die kerk staan prinsipieel los van en teenoor die staat (Hendriks 1977:104). Nie die kerk of die staat ontleen hulle mag aan mekaar nie. "Dit is God self wat die twee magte, die kerk en die staat, in die wêreld gestel het" (Engelbrecht 1963:112).

Tog kom hier iets van 'n dialektiese spanning tussen die twee, kerk en staat, na vore. Dit word duidelik uit die feit dat, as die kerk hom rig tot die owerheid, hy net maar besig is om die owerheid te dien (Van Ruler 1947b:210). Daarom geld die volgende: "Samengevat gaat het bij de profetie tot de overheid dus om deze drie dingen: voorbede bij God voor de overheid, voorspraak voor de overheid bij de volk, voorlichting van de overheid uit het Woord. In al deze drie aspecten komt uit, dat de kerk een dienende 
(maar toch niet ondergeschikte!) taak tegenover de overheid heeft" (Van Ruler 1973: 102).

Die waarheid het God aan die kerk geskenk en die mag aan die staat (Van Ruler 1947b:211). Daarom is kerk en staat afhanklik van mekaar. "Wij vonden als grondnotie van de zuivere verhouding van het christendom en de politiek, dat de kerk in het huwelijk heeft te treden met den staat" (Van Ruler 1947b:236). Die beeld wat Van Ruler gebruik om dit uit te beeld, naamlik die van die ellips met twee brandpunte, beskryf hierdie verhouding tussen kerk en staat goed.

Die feit dat kerk en staat aan mekaar verbonde is, hou in dat die staat nooit neutrale staat kan wees nie, maar altyd staat met die Bybel behoort te wees (Hendriks 1977:105-106). Dit beteken verder ook dat die staat die kerk moet beskerm, selfs met die swaard. Dit sou ook billik van die staat wees om die kerklike amptenare te vergoed vir hulle werk, asook om die kerklike eiendomme in stand te hou (Van Ruler 1945:349). Hiernaas is dit ook belangrik dat die staat die kerk moet bevorder (Van Ruler 1945:350), want dit is beide kerk en staat se verantwoordelikheid om die volkslewe te orden en te dien.

\subsection{Die volkskerk}

Die debat oor die volkskerk is nie nuut in die Nederduitsch Hervormde Kerk [Kerk] nie. Daarvan getuig die ongeveer 100 artikels in die kerklike tydskrifte sedert 1980. Dat die Kerk in sy nadenke oor die saak deur Van Ruler beïnvloed is, blyk onder andere uit die feit dat P J T Koekemoer drie artikels in Die Hervormer (1987:16, 14; 1997a:2; 1997b:6) wy aan Van Ruler se verstaan van die volkskerk. Botha (1990:489) sê dat Van Ruler 'n groot invloed op Koekemoer uitgeoefen het. Ook verskeie ander teoloe in die Kerk het Van Ruler aangehaal oor die volkskerk (vgl Botha 1973; Van der Westhuizen 1981; Pont 1981). Die feit dat Van Ruler so dikwels in die Kerk aangehaal word, is verstaanbaar, aangesien Van Ruler in sy geskrifte die volkskerk gereeld verdedig het. Dit is dus duidelik dat die invloed wat Van Ruler op die Kerk uitgeoefen het, en steeds uitoefen, nie geringgeskat kan word nie. Wat Van Ruler oor die volkskerk sê, is nie vreemd vir die Kerk nie. Die Kerk praat Van Ruler in 'n groot mate na oor die volkskerk. 
Om iets van Van Ruler se verstaan van die volkskerk te probeer weergee is baie moeilik. Ook vir Koekemoer (Die Hervormer 1987:16) is dit 'n "onbegonne taak ... om Van Ruler se teologie te benader met die gedagte dat jy een of ander enkele teologiese begrip uit die groot geheel netjies gaan 'abstraheer' om dit op 'n teologiese tafel te gaan uitstal". Om dié rede kan hier net kortliks iets van sy verstaan van die volkskerk weergegee word.

"In die denke van Prof. van Ruler word gedurig beklemtoon dat die kerk daar is ter wille van die wêreld" (Van Rooyen 1964:79). Dit is juis in hierdie wêreld waarin God gestaltes van sy koninkryk wil oprig. Die kerk is vir die doel op aarde geplaas om die totaliteit van positiewe tekens van die koninkryk van God te wees (Van Rooyen 1964: 80). Die kerk is dus ook, as totaliteit van die positiewe tekens, daar ter wille van die staat en die volk en wil die koninkryk van God op aarde oprig (Van Rooyen 1964:80). So raak die verhouding van kerk en staat met mekaar vervleg.

Die volgende aanhaling kan as uitgebreide definisie geld van wat Van Ruler onder volkskerk verstaan:

Een kerk is dan in den echten zin van het woord volkskerk, wanneer zij voor deze rijksbedoelingen Gods met de volkeren der aarde en met hun culturen de oogen open houdt; wanneer zij vasthoudt aan de beloften van het koninkrijk, centraal aan de beloften, dat de overheid de dienaresse in het rijk Gods is, en alomvattend aan de beloften, dat de levende God op de aarde veelvormig gediend zal worden; wanneer zij deze perspectieven op het gewone leven en op de wereld en op de cultuur en op den staat zich niet laat verduisteren, door welke goddelooze of vrome overwegingen ook, en verstaat, dat hier het eigenlijke van de bedoelingen van het hart Gods ligt ... Een volkskerk is een kerk, welke in al haar doen en laten, in al haar spreken en handelen bezig is met de publieke zaak van het volksleven en het licht van de waarheid uit het Woord Gods laat uitstralen, opdat de overheid in haar regeering van het volksleven in dit licht zou wandelen.

(Van Ruler 1947b:225-226) 
Vir Van Ruler is die belangrikste kenmerk van die volkskerk daarin geleë dat die volkskerk hom met die Woord van God tot die owerheid rig (Hendriks 1977:110; Die Hervormer 1987:14). Dit word ook duidelik uit bogenoemde definisie van die volkskerk. Omdat die kerk ter wille van die wêreld in aansyn geroep is "impliseer dit dan ook dat die kerk daar is ter wille van die staat om welke gesagskern die volk gesentreer is" (Die Hervormer 1987:14). Deur met die Woord teenoor die staat te getuig, staan die kerk in die midde van die volkslewe (Die Hervormer 1987:14). "So gesien is die kerk ook daar ter wille van die volk, want die volk is altyd tog volk rondom die gesagskern" (Van Rooyen 1964:80). Dit gaan dus in die volkskerk om die staat ter wille van die volk.

Van Ruler gaan sterk uit van die volk, omdat dit volgens hom is wat die $\mathrm{Ou}$ Testament leer. Dit gaan in die Ou Testament immers om die hele volk. Dit word duidelik deurdat Van Ruler (1947b:115) sê dat die tora "een eigen gestalte des levens, een levensvorm voor het volk en voor den enkeling" ontwerp. In die tora gaan dit oor die nasionaal-simboliese lewensvorm van Israel. "Dit gaan om die hele Israel! En dan nie alleen om alle mense in Israel nie, maar om alle dinge in Israel!" (Van Rooyen 1964:87). Die tora rig die volk tot in sy fynste besonderhede in (Van Ruler 1947b:115). Wat verder van belang is, is die feit dat die volkslewe van Israel openbaringsbetekenis het vir vandag. "Men moeten werkelijk het heele Oude Testament laten vallen, wanneer men deze dingen in de bijbelsche boodschap als tijdelijke beperkte vormen en omhulsels zou willen verstaan" (Van Ruler 1947b:119-120).

Hierdie verstaan van die tora gaan egter nie op nie. Die tora is nie ontwerp om die samelewing in te rig nie, maar eerder om ' $n$ volk wat in verhouding met God getree het, in 'n lewe van dankbaarheid te lei (vgl Breytenbach 1997:705-706). Dit geld nie net vir Israel nie, maar ook vir die gelowiges van vandag.

Daar is baie ander uitsprake van Van Ruler wat bekend klink in die Kerk. Daaronder tel die volgende:

- Die volkskerk is nie 'n kerk waarin die volk sy religieuse lewe tot uitdrukking bring nie. Dit is eerder Christus-belydende volkskerk (Hendriks 1977:110; Van Ruler 1947b:225).

- Die volkskerk is nie 'n kerk wat daarvan droom om die hele volk te omvat nie (Hendriks 1977:111). 
- Die regte verstaan van die verbondsgedagte lei tot die volkskerkgedagte (Botha 1989:27; Hendriks 1977:11).

Hierdie en ander gedagtes is nie vreemd in die Kerk nie. Daaruit kan gesien word dat die invloed wat Van Ruler op die volkskerkdenke in die Kerk uitgeoefen het, groot is. Daarmee word nie ontken dat andere, soos Hoedemaker, ook 'n groot invloed uitgeoefen het op die verstaan van die Kerk as volkskerk nie. Die invloed van Van Ruler mag egter nie geringgeskat word nie.

Dat die kerk as volkskerk vir Van Ruler 'n kultuurtaak het, staan vas. Alle kultuur is politiek gevormde kultuur (Hendriks 1977:97). Daarom is dit nodig dat die kerk teenoor die staat getuig, want soos die staat ingerig word, word die kultuur gevorm (Van Ruler 1947b:9). Die skep van die kultuur kan en mag nie los van die getuienis van die kerk geskied nie. Die kerk het hierin 'n belangrike rol om te vervul (Van Ruler 1972b:99-103). Wanneer "de openbaring ... onder een volk optreedt, dan ontstaan er cultuur. Het is de Woord Gods dat de eigenlijke cultuur op aarde schept" (Hendriks 1977:98). In die skep van die kultuur moet die Ou Testament spesifiek aan die woord kom, want die tora ontwerp die gestalte van die lewe (Van Ruler 1947b:125). Op grond hiervan het die volkslewe van Israel openbaringsbetekenis (Van Ruler 1947b:120). Die kultuurtaak van die kerk kom juis na vore in die gedagte van die teokrasie. Die kerk moet altyd teenoor die staat getuig, wat op sy beurt die kultuur polities vorm (Van Ruler 1947b:210; Hendriks 1977:97). Juis deurdat die kerk teenoor die staat getuig, staan die kerk in die midde van die volk en word hy volkskerk (Die Hervormer 1987:14). Dat die kerk 'n kultuurtaak het, kan dus afgelei word uit wat Van Ruler onder teokrasie en die volkskerk verstaan. Die ryk van God moet opgerig word in die midde van die volk. Daarin het die kerk ' $n$ baie belangrike rol om te vervul (Van Ruler 1972b:99).

\section{VAN RULER SE HERMENEUTIEK VAN DIE OU TESTA- MENT}

\subsection{Van Ruler se gebruik van die Ou Testament om sy teologie te bevestig}

Op hierdie punt is dit belangrik om te vra na Van Ruler se hermeneutiese uitgangspunte in sy uitleg van die Ou Testament. Een van die belangrike uitgangspunte volgens Van 
Ruler (1971:24) is dat daar nie met 'n vooropgestelde konsep na die Ou Testament gegaan moet word om hierdie konsep dan weer daarin terug te vind nie. Dit sou byvoorbeeld verkeerd wees om met 'n sekere dogmatiese interesse die Ou Testament te benader. Die vraag is egter of dit nie juis is wat Van Ruler in sy gebruik van die Ou Testament doen nie. Daar is reeds op gewys dat Van Ruler se teologie nie die volle konsekwensies van die eskatologie in ag neem nie. Van Ruler se eskatologie veroorsaak by hom ' $n$ teruggrype in die verlede, sonder dat die vooruitgang na die eskaton ten volle uitgebou word. Die gevolg daarvan is dat daar in die hede vorme geskep moet word om die koninkryk van God te vergestalt. En waar sal Van Ruler 'n beter bron vir die vorme en gestaltes vind as in die Ou Testament (Rasker $s$ a:19)? Brinkman (in Vlijm 1981:149) is waarskynlik korrek wanneer hy sê: "Van Ruler durft zich ten aanzien van het dogma tamelijk vrij ten opzichte van de Schrift op te stellen, omdat hij zo nadrukkelijk ... de menselijke denkarbeid als vrucht van het werk van de Heilige Geest honoreert en dientengevolge als skopus van de openbaring Gods typeert."

Om hierdie rede kan Van Ruler byvoorbeeld sê dat die bedoeling van die Mosaiese wet is om die gekerstende en te kerstende wêreld in te rig. Met hierdie standpunt neem Van Ruler nie die bedoeling van die Mosaïese wet in aanmerking nie. Omdat die Tien Gebooie deel uitmaak van die verbond van God met Israel, is dit lewensreëls waarmee die mense met wie JHWH in verhouding getree het by Sinaï, hulle lojaliteit teenoor Hom kan uitleef (Deut 6:4-9):

Die saak waaroor dit dus gaan, is nie die ordening van die samelewing nie, maar die verhouding wat God in sy genade en onverklaarbare liefde met Israel geskep het (Deut 7:7-11). Die vrywillige nakoming van die gebooie is Israel se antwoord op God se liefde, en sulke lojaliteit en dankbaarheid maak weer 'n stortvloed liefde van God se kant af los (Deut 7:12-15).

(Breytenbach 1996:705-706)

Dit word duidelik dat Van Ruler die Ou Testament gebruik om sy teologie te bevestig, eerder as om na die oorspronklike bedoeling van 'n spesifieke teks van die $\mathrm{Ou}$ 
Testament te vra. Dit gaan nie in die tora om die inrigting van die samelewing nie. So 'n uitleg van die Mosaïese wet is 'n growwe mistasting.

\subsection{Voorbeelde van Van Ruler se gebruik van die Ou Testament}

Bogenoemde standpunte behoort duidelik te word in die volgende voorbeelde van Van Ruler se eksegese. In 'n populêre werk, wat kort oordenkings oor verskeie psalms bevat (Van Ruler 1973), word dit duidelik dat Van Ruler se dogmatiek sy verstaan van die psalms grootliks bepaal het. In verskeie van die oordenkings kan gesien word dat Van Ruler nie die oorspronklike bedoeling van die psalms in aanmerking neem nie, maar dit eerder uitlê in die lig van sy eie teologie. Om dit aan te dui, word hier nie in besonderhede op ondergenoemde twee psalms ingegaan nie. Slegs tersaaklike eksegetiese en hermeneutiese kommentaar word gelewer.

\subsubsection{Psalm 2}

In die oordenking oor Psalm 2 is dit duidelik dat Van Ruler nie die eie aard van die psalm in aanmerking neem nie. Vir Van Ruler gaan dit in die psalm om die samelewingsvorm van Israel en die volke. Dit gaan volgens hom daaroor dat die koning van Israel, as gesalfde van die Here, reg en geregtigheid oor Israel en oor die hele aarde moet laat seëvier. Van Ruler sê onder andere die volgende oor die psalm:

[I]n dat volk gaat het centraal om het koningschap, en om de samenlevingsvorm, om de oprichting van het recht en de gerechtigheid. En men heeft van meet af gezien dat deze dingen van God komen, vanuit zijn toekomst .... God heeft zijn koning gesteld over Sion .... Nú kan het leven ingericht, geordend en gevormd worden vanuit Gods oorspronkelijke en uiteindelijke bedoelingen .... De snoeren van Gods wet gaan uit over de hele aarde.

(Van Ruler 1973:11)

Dit is dus die koning van Israel wat die verantwoordelikheid het om vanuit Sion, die nasies wat God nie dien nie, onder die heerskappy van God te bring. Die volkere, state en kulture moet onder die ryk van Christus gebring word (Van Ruler 1973:12). 
Hierdie uitleg van Psalm 2 is te verstane in die lig van wat reeds gesê is oor Van Ruler se eskatologiese en teokratiese gedagtes. Die vraag is egter of Psalm 2 hierdie strekking het.

Die meeste verklaarders is dit eens dat Psalm 2 ' $n$ troonsbestygingspsalm is of ' $n$ psalm wat ontstaan het na aanleiding van die jaarlikse inhuldigingseremonie van 'n koning van Israel, waarskynlik voor die ballingskap (Weiser 1962:109; Anderson 1972:63; Taylor 1991:23). Dit kon ook sy ontstaan gehad het na aanleiding daarvan dat sekere vasalkonings in opstand gekom het teen die koning van Israel by geleentheid van 'n troonswisseling (Van Uchelen 1971:16; Taylor 1991:23). Dit sou ook meer universeel gerig kon wees, sonder dat daar 'n spesifieke historiese situasie in gedagte gehou behoort te word (Anderson 1972:64). Wat ook al die historiese omstandighede was, die psalm veronderstel 'n situasie waarin die vertroue uitgespreek word dat God die koning sal help tydens die opstand van die nasies en hulle konings (vgl Weiser 1962:109-110; Taylor 1991:23). Die psalm het dus 'n politieke strekking in die sin dat nasies teen hulle oorheersers in opstand kom. Dit het ook 'n religieuse strekking in die sin dat die koning in die psalm weer daarvan verseker word dat hy, as "seun" van God, van God self hulp sal ontvang om die stryd teen die nasies te wen. Dit gaan dus nié daaroor dat die koning die nasies rondom die wet moet vergader om so die wêreld in te rig volgens God se gebooie nie. Die enigste hoop vir die nasies lê daarin dat hulle en hulle vorste God moet dien.

Die laaste strofe (verse 10-12) mag die indruk wek dat dit hier slegs daaroor gaan dat God deur die konings gedien moet word, en dat die politieke perspektief hier verlore gaan. Dit is egter nie korrek nie. Om die Here te dien, beteken om onderdanig te wees aan die koning as seun van God (Anderson 1972:69). In die feit dat die nasies die Here moet dien, lê dus ook die gedagte opgesluit dat die koning oor die nasies sal regeer. "[A]s the regent of the God of the whole earth, and the champion of Israel his people, the king had the right to rule over the nations" (Hamlin 1962). Alhoewel hier tog van 'n politieke perspektief sprake is, is dit so dat die klem in die laaste strofe meer op die aanbidding van God as op die koning van Israel val. In 'n sekere mate het die koning van Israel in die strofe op die agtergrond verdwyn en gaan dit daaroor dat God die Koning van die konings is wat gedien moet word (vgl Weiser 1962:115-116). Dit het dus 'n sterk religieuse strekking. Ook uit hierdie gedeelte kan nie afgelei word dat die samelewing 
ingerig moet word rondom die wet van God nie. Dit gaan slegs daaroor "to show that God is the Lord and to make sure that he will be recognised as such" (Weiser 1962:115).

Samevattend kan dus gesê word dat dit in Psalm 2 nie daaroor gaan dat die koning deur sy regering oor die nasies, die nasies se samelewings moet inrig rondom die wet van God nie. Dit gaan hier oor die feit dat die vertroue uitgespreek word dat die koning deur God bygestaan sal word as die nasies in opstand kom. Die feit dat Van Ruler die inrigting van die samelewing deur die hand van die koning in hierdie psalm raaksien, het daarmee te doen dat Van Ruler se dơgmatiek en teologie sy eksegese beslissend bepaal.

\subsubsection{Psalm 7}

Nog 'n voorbeeld hiervan is Van Ruler se uitleg van Psalm 7. Vir Van Ruler gaan dit in die psalm oor die onreg wat daar op die aarde is. Dit gaan oor die koning as verteenwoordiger van sy volk wat namens die volk kla oor die onreg en geweld wat die aarde oorspoel en oor die feit dat die saak van God deur die geweld van die nasies aangetas word. Omdat dit vir God oor die aarde gaan, is dit ook reg dat die koning sy klag in gebed voor die Here uitstort. Van Ruler vat dit soos volg saam: "De hele bijbel is op de zuivere samenlevingsvorm gericht" (Van Ruler 1973:23). God wil dat die samelewing een sal wees waarin liefde en geregtigheid seëvier. Die koning kla voor God omdat die volkere deur geweld die saak van God aantas. Dit gaan dus in die psalm vir Van Ruler daaroor dat die volke deur God geoordeel sal word. Daarom is die opskrif by die uitleg ook: Het gericht (Van Ruler 1973:22-24).

Dit lyk egter of Van Ruler, omdat sy teologie teokraties bepaal is, die klem van die psalm op die verkeerde saak laat val. Dit gaan in die psalm nie in die eerste plek oor die cordeel oor die volkere nie, maar oor die klag van 'n persoon wat in die tempel sy hart voor God uitstort oor die onreg wat teen hom gepleeg word. Die feit dat die opskrif van die psalm dit toeskryf aan Dawid, het Van Ruler moontlik daartoe gelei om te sê dat die psalm die klag van die koning is wat die volk verteenwoordig. Die opskrif is egter 'n latere toevoeging wat nie enige historiese situasie reflekteer nie (Anderson 1972:92-93; Van Uchelen 1971:46). Die onreg wat gepleeg word, dui nie soseer op onreg in die samelewing nie, maar op onreg teen die klaer. Dit gaan dus nie daaroor dat die vyand se samelewing ingerig moet word rondom die wet nie, maar eerder daarom dat die vyand 
geoordeel moet word vir sy vervolging van die klaer. Die klaer kry gemoedsrus omdat hy onskuldig staan voor God, terwyl God self oor sy vyande sal oordeel.

\section{3 'n Diversiteit van teologieë}

'n Verdere probleem is die feit dat Van Ruler die diversiteit van teologieê in die $\mathrm{Ou}$ Testament oor die hoof sien. Die vraag is of daar 'n sentrale tema soos die teokrasie, met sy verwante temas soos die koninkryk van God, in die hele Ou Testament in te lees is, en dit die enigste moontlike teologie vir die Ou Testament is. Dieselfde kan gevra word in verband met die tema van die vervulling van die Ou Testament deur Jesus Christus (vgl Breytenbach 1996:706-707). Die inlees van een of twee teologiese temas in die hele Ou Testament, asof ander moontlikhede nie bestaan nie, is ' $n$ onkritiese omgaan met ' $n$ teks wat in ' $n$ verskeidenheid van omstandighede sy ontstaan gehad het. Daar is eerder van 'n diversiteit van teologieë sprake as van een sentrale teologie wat soos 'n lyn deur die hele Ou Testament loop (Goldingay 1987:1-28; Hanson 1982:xv-xviii; Brueggemann 1980:218). In die afgelope dekades het "[r]esultate van veral tradisiekritiek, redaksie-kritiek en ideologiekritiek ... daartoe gelei dat die beeld van 'n eenduidige 'boodskap' of teologie van die Ou Testament afgebreek is .... Die paradigmaverskuiwing weg van die streng histories-kritiese benadering het hierdie diversiteit in die Ou Testament bevestig" (Breytenbach 1997:1162). Die teologiese diversiteit van die Ou Testament word algemeen aanvaar deur Ou-Testamentici en "geen Bybelwetenskaplike van formaat [sal] meer vandag die standpunt handhaaf dat die Ou Testament 'n sentrale tema het wat deur 'n term soos 'koninkryk' of selfs 'verbond' aangedui kan word nie" (Breytenbach 1996: 706-707).

Hierdie diversiteit kom by Van Ruler nie tot sy reg nie. Dit is inderdaad begrippe soos koninkryk, verbond en teokrasie wat in die werk van Van Ruler sterk op die voorgrond tree (vgl byvoorbeeld Van Ruler 1971:29). Dit is omdat Van Ruler die

diversiteit nie in aanmerking neem nie, dat hy die Ou Testament kan gebruik om sy teologie te begrond. Vandag kan daar nie meer so eensydig met die Ou Testament omgegaan word nie. Hierdie werkwyse van Van Ruler, waar hy met 'n voorafontwerpte 
denkskema na die Ou Testament gaan, veroorsaak by hom 'n eensydige inlees van begrippe en gedagtes wat vir hóm in sy teologie belangrik is.

\subsection{1 'n Diversiteit rondom die teokrasie}

Selfs binne die teokratiese ideaal van die Ou Testament is daar 'n diversiteit wat Van Ruler nie in aanmerking neem nie. Van Ruler bou sy teokrasie op rondom die gedagte dat kerk en staat onlosmaaklik aan mekaar verbonde is en as twee brandpunte in 'n ellips teenoor mekaar staan (Van Ruler 1945:153; 1947b:210; Fries 1973:208). Vir Van Ruler is die oorsprong van die staat, en daarom ook van die verhouding van kerk teenoor staat, te vinde in die figuur van Melgisedek, koning van Salem (Gen 14; Engelbrecht 1963:94; Van Ruler 1945:173). Dit word afgelei uit die feit dat Melgisedek koning én priester was. Uit die feit dat Melgisedek priester-koning was, maak Van Ruler verskeie gevolgtrekkings oor die staat. So sê hy byvoorbeeld:

Inderdaad: de staat is een figuur van deze wereld, maar hy bewaart het heil op de aarde; hij staat in een zee van heidendom, maar hij is dienaar van God; hij is geroepen om de kerk te zegenen .... Men kan den staat niet abstraheeren van de kerk, om eerst het verschijnsel van den staat geïsoleerd in het 00 te vatten en te trachten, dit verschijnsel te doorgronden, om dan pas later de kerk te laten optreden, op het terrein van den staat .... Deze probleemstelling hangt samen met het fundamenteele theocratische inzicht, dat de staat pas door de kerk tot zijn ware wezen komt.

(Van Ruler 1945:173-174)

Op grond van die voorbeeld van Melgisedek maak Van Ruler dus die gevolgtrekking dat staat en kerk nou aan mekaar verbonde is. Die een is nie los te maak van die ander nie. Melgisedek was immers priester-koning.

Deurdat Van Ruler dit sê, neem hy nie die diversiteit van die teokrasie in die Ou Testament in aanmerking nie. Szikszai (1962:617a) onderskei byvoorbeeld drie tipes teokrasiez in die Ou Testament. Die eerste hiervan is die charismatiese teokrasie. "The king of this politically unorganized amphictyony was the Lord" (Szikszai 1962:617). Daar was geen sentrale politieke of militêre organisasie waarin 'n sentrale figuur as 
verteenwoordiger van God opgetree het nie. Die charismatiese leiers, of rigters, het deur die leiding van die Gees van die Here as tydelike verteenwoordigers van God opgetree en so die teokratiese regering van God vergestalt. Hierdie soort teokrasie verskil van dié wat Van Ruler poneer en wel in dié opsig dat daar geen geïnstitusionaliseerde verteenwoordiger van die teokrasie was nie.

Die tweede tipe teokrasie was die monargale teokrasie. Hier was die koning die geïnstitusionaliseerde verteenwoordiger in diens van die teokrasie. Daarom het hy ook sekere godsdienstige funksies vervul (Szikszai 1962:618). Hierdie beeld sluit nou aan by dié van Melgisedek, en val dus meer binne die perspektief wat Van Ruler daarop nahou. Dit is interessant om daarop te let dat die verhaal van Melgisedek deur sommige geleerdes aan die Jahwistiese bron toegeskryf word (Gottwald 1985:151). Dit sou beteken dat dit deur die Jahwis opgeneem is in ongeveer $930 \mathrm{vC}$ (Gottwald 1985:137; vgl Loader 1987:15-20) toe die monargie goed gevestig was en die koning van Jerusalem reeds sy priesterlike en koninklike funksies vervul het. Dit is waarom daar aan Melgisedek, koning van Salem (wat waarskynlik Jerusalem is, vgl Simpson 1990:596; Barrois 1962:166), ook 'n priesterlike rol toegeken word (Simpson 1990:597). Ek is oortuig daarvan dat Van Ruler nie hierdie agtergrond in aanmerking geneem het in sy verduideliking van die verband tussen kerk en staat, soos dit in sy verstaan van die figuur van Melgisedek na vore tree nie.

Die derde tipe teokrasie is die priesterlike teokrasie (Szikszai 1962:618). Die afwesigheid van 'n Joodse monarg tydens die Persiese bewind het daartoe bygedra dat die priester se gesag toegeneem het. Dit het die priesterlike teokrasie tot gevolg gehad waar God deur die priester as sy verteenwoordiger regeer sonder dat daar van 'n geinstitusionaliseerde staat sprake is. Esegiël en Deutero-Jesaja was voorstanders hiervan (vgl Vosloo 1986:219 en 222-223). Deutero-Jesaja verkondig byvoorbeeld nêrens dat die Dawidsdinastie in politieke sin herstel sal word nie (Vosloo 1986:223). Ook in die naeksiliese profete word hierdie tendens voortgesit. In Sagaria kan gesien word hoe die persoon van die hoëpriester die figure van koning en profeet op die agtergrond laat verdwyn. "Met die verdwyning van Serubbabel van die toneel, het die posisie van die 
hoëpriester nog meer verstewig sodat daar kort voor lank 'n hiërokrasie (priesterheerskappy) ontstaan het" (Vosloo 1986:232-233).

Dit is dus duidelik dat daar in die Ou Testament verskeie vorme van die teokrasie moontlik was. Van Ruler neem dit nie in aanmerking in sy teologie nie. Hy gaan uit van die monargale vorm van teokrasie sonder om die diversiteit rondom die teokrasie in ag te neem.

\section{SAMEVATTING}

Dat Van Ruler as teoloog groot invloed uitgeoefen het op die Kerk kan nie betwyfel word nie. Van Ruler se insigte oor die teokrasie en die volkskerk, as vorme vir die inrigting van die samelewing, het in die Kerk beslis aanklank gevind. Om hierdie rede is dit noodsaaklik om die werk van Van Ruler, en die neerslag wat dit in die Kerk gevind het, krities te beoordeel. Dit is duidelik dat die korrekte inrigting van die samelewing by Van Ruler ' $n$ belangrike element van sy teologie uitmaak. Die inrigting van die samelewing wil hy onder andere bereik deur die teokrasie te laat herlewe na aanleiding van sy eie verstaan daarvan. Hierby sluit die volkskerk aan, aangesien die volkskerkgedagte juis 'n vorm van teokrasie sou wees wat deur sy getuienis teenoor die staat in die midde van die volk staan.

Dit het uit die studie duidelik geword dat dit teologies onverantwoordelik sou wees om Van Ruler se standpunt onkrities te bly handhaaf. Van Ruler se gebruik van die Ou Testament is niks anders as 'n legitimering van 'n vooraf ingenome standpunt nie. Sy teologies-dogmatiese konstruk wat opgebou is rondom bepaalde temas, neem nie die eie aard van die Ou Testament in ag nie. Alleen só kry Van Ruler dit reg om sy teologie, waarin die eskatologie, die koninkryk van God, die teokrasie en die volkskerk sentraal staan, in die Ou Testament te begrond.

Indien die Kerk verantwoordelik wil besin oor sy eie plek en rol in die samelewing en as hy homself steeds wil handhaaf as 'n volkskerk, sal hy hom deeglik moet afvra in hoe 'n mate sy denke in dié verband deur Van Ruler se teologisering bepaal is. Die Kerk sal moet deurvra na Van Ruler se begronding van sy teologiese standpunte op die Skrif. Van Ruler se gebruik van die Ou Testament sal in elk geval nie die toets van verantwoordelike eksegese en teologisering slaag nie. 


\section{Literatuurverwysings}

Anderson, A A 1972. Psalms, vol 1. Somerset: Purnell \& Sons. (NCB.)

Barrois, G A 1962. s v Salem. IDB.

Berkhof, H 1990. Christelijk geloof: Een inleiding tot de geloofsleer. Nijkerk: Callenbach.

Botes, H J 1996. Die kerk se verantwoordelikheid teenoor die onderwys: Is Artikel X van die Kerkwet (1986) van die Nederduitsch Hervormde Kerk van Afrika teologies verantwoordbaar? HTS 52(4), 931-946.

Botha, S J 1973. Die volkskerk. Pretoria: HAUM.

- (red) 1989. Belydende volkskerk. Pretoria: Kital.

Botha, S J 1990. Petrus Johannes Teobaltus Koekemoer: 'n Teoloog saam met en soos die kerk. HTS 46(4), 487-496.

- 1996. Die Corpus Christianum in die Middeleeue. HTS 52(4), 800-819.

Breytenbach, A P B 1996. Die gebruik van die Ou Testament in die begronding van die kerk se kultuurtaak - 'n hermeneutiese probleem. HTS 52(4), 693-714.

- 1997. Meesternarratiewe, kontranarratiewe en kanonisering: 'n Perspektief op sommige profetiese geskrifte. HTS 53(4), 1161-1186.

Brueggemann, W 1980. A convergence in recent Old Testament theologies. JSOT 18, 218.

Deist, F E 1987. Die Heksateug, in Bosman, H L \& Loader, J A (red), Die literatuur van die Ou Testament, Deel 2, 1-39. Kaapstad: Tafelberg.

Dreyer, W A 1996. Kerk-kultuur-volk-owerheid. HTS 52(4), 863-893.

Engelbrecht, B 1963. Agtergronde en grondlyne van die teokratiese visioen: 'n Inleiding tot die teokratiese teologie van prof A A van Ruler. DD-proefskrif, Universiteit van Suid Afrika.

Goldingay, J 1987. Theological diversity and the authority of the Old Testament. Michigan: Eerdmans.

Gottwald, N K 1985. The Hebrew bible: A socio-literary introduction. Philadelphia: Fortress.

Fries, P 1973. Van Ruler on the Holy Spirit and the salvation of the earth. Reformed Review 26(2), 123-135. 
Haitjema, L \& Van Niftrik G C 1956. Theocratie en eschatologie: Een briefwisseling. Wageningen: Veenman.

Hamlin, E J 1962. s v Nations. IDB.

Hanson, P D 1982. The diversity of Scripture. Philadelphia: Fortress.

Die Hervormer Oktober 1987. A A van Ruler oor die volkskerk, bl 14 \& 16.

Die Hervormer 1 Augustus 1997a. Nederduitsch Hervormde Kerk - 'n volkskerk, bl 2.

- 15 Oktober 1997b. Van Ruler en die volkskerk, bl 6.

Hendriks, A N 1977. Kerk en ambt in de theologie van A A van Ruler. DD-proefskrift, Theologiese Hogeschool van de Gereformeerde Kerken in Nederland te Kampen.

Hesselink, J 1973. Contemporary Protestant Dutch Theology. Reformed Review 26(2), 67-89.

Kempers, E M L (red) 1997. Inventaris van het archief van prof dr Arnold Albert van Ruler (1908-1970). Utrecht: Universiteitsbibliotheek Utrecht.

Nuwe Afrikaanse Bybelvertaling, 1983.

Pelser, G M M 1996. Die verhouding kerk en wêreld/kultuur. HTS 52(4), 715-733.

Pont, A D 1981. Die historiese agtergrond van ons kerklike reg. Pretoria: HAUM.

Rasker, A J s a. Christelijke politiek: Gesprek over de theocratie. Nijkerk: Callenbach.

Simpson, A 1990. Genesis. Nashville: Abingdon. (IB.)

Szikszai, S 1962. s v Theocracy. IDB.

Taylor, W R 1991. Psalms, Proverbs. Nashville: Abingdon. (IB.)

Van Der Westhuizen, H G 1981. Volkskerk en sending. Pretoria: HAUM.

Van Ruler, A A 1945. Religie en politiek. Nijkerk: Callenbach.

- 1947a. De vervulling van de wet: Een dogmatische studie over de verhouding van openbaring en existentie. DD-Proefskrift, Rijksuniversiteit te Groningen.

- 1947b. Droom en gestalte: Een discussie over de theologische principes in het vraagstuk van christendom en politiek. Amsterdam: Holland.

- 1947c. Visie en vaart. Amsterdam: Holland.

- 1969. Theologisch werk, Deel $I$. Nijkerk: Callenbach.

- 19702. Waarom zou ik naar de kerk gaan?. Nijkerk: Callenbach.

- 1971. The Christian Church and the Old Testament, tr by G W Bromiley. Grand Rapids: Eerdmans. 
Van Ruler, A A 1972. Theologisch werk, Deel V. Nijkerk: Callenbach.

- 1973. Over de psalmen gesproken. Nijkerk: Callenbach.

Van Rooyen, J H P 1964. Kerk en staat: 'n Vergelyking tussen Kuyper en Van Ruler. DD-proefskrift. Rijksuniversiteit te Utrecht.

Van Uchelen, N A 1971. Psalmen, Deel 1. Nijkerk: Callenbach. (POT.)

Van Wyk, D J C 1990. P J Hoedemaker: "Wat ek bedoel, is die behoud van die kerk". HTS 46(4), 497-512.

Velema, W H 1962. Confrontatie met Van Ruler: Denken vanuit het einde. Kampen: Kok.

Vlijm, J M (red) 1981. Geloofsmanieren: Studies over pluraliteit in de kerk. Kampen: Kok.

Vosloo, W 1986. Meer as net 'n storie. Goodwood: Nasionale Boekdrukkery.

Weiser, A 1962. The Psalms, tr by Herbert Hartwell. London: SCM Press. (OTL.) 